\title{
Student's Perspectives on Prevention Strategies of Social Media Addiction Effects in Selected Colleges of Education on the Copperbelt Zambia
}

\author{
Harry Jordan Silomba $^{1 *} \quad$ Akakandelwa Akakandelwa $^{2} \quad$ Sophie Kasonde $\mathrm{Ng}$ 'andu $^{3}$ \\ 1. School of Education, Mufulira College of Education, PO box 40400, Mufulira, Zambia \\ 2. School of Library and Information Science, University of Zambia, PO box 32379, Lusaka, Zambia \\ 3. School of Education, University of Zambia, PO box 32379, Lusaka, Zambia
}

\begin{abstract}
Social Media Addiction (SMA) effects have been recognised as a significant psychological health problem in many countries. Yet, few investigations have been conducted on SMA effects intervention strategies globally and almost none in Zambia. This study sought to explore strategies that may lessen the adverse effects of SMA on student's psychological well-being in selected colleges of education on the Copperbelt province of Zambia. The study employed a qualitative case study research design involving 64 participants. Data were collected using the Focus Group Discussion (FGD), and interviews, whereas, the analysis was done with the help of a framework analysis approach to generate study themes. The results revealed that the student's addictive usage of social media adversely affected their psychological well-being. The study spelt out various intervention strategies centred on government, colleges and guidance and counselling interventions levels. Practically, it has been anticipated that the ideas discussed under each level may facilitate effective and tailored intervention programs to reduce SMA effects among the students.
\end{abstract}

DOI: $10.7176 / \mathrm{JEP} / 12-3-17$

Publication date: January $31^{\text {st }} 2021$

\section{Introduction}

In recent years, the field of social media has seen its unpreceded growth in the number of innovations and users. Social media which include all aspects of platforms, such as Facebook, WhatsApp, Twitter, Instagram, has dramatically changed the way individual interact. It has the power to remove geographical and physical access barriers amongst humanity. Conversely, social media compels individuals to live practically online and it has the potential to make them addicted (Griffith, 2013). Consequently, with the increase in social media use throughout individuals' daily lives, SMA effects are gaining recognition (Niranjjan et al., 2017) of which students are not exceptional (İbrahim, 2019). As it is known, most students' social media use is habitual enough that it spills over negatively into other areas of their lives (İbrahim, 2019). Past studies have suggested that a relationship exists between SMA and college students' psychological illness. To this end, such studies have yielded results of depression stress and anxiety (Pantic et al., 2012; Aydogan \& Buyukyilmaz, 2017; İbrahim, 2019).

Subsequently, a study that was done by Echeburúa and Corral (2010) also claimed that social media addictive individuals exhibit symptoms that are similar to those people who suffer from addictions to substances such as drugs. As such, the vice requires effective control solutions. However, with the constant innovations surrounding the social media fraternity, which brings about the availability of captivity platforms apps, it might be challenging in redefining students' self-control abilities. The trend may pose challenges in intervention strategies, based on the absence of a solid foundation that can recognise social media addiction as a disorder (DSM, 2017).

The preceding observation signifies confusions surrounding the media fraternity and has enormous implications for college authorities. Unlike treatment for other addictions such as drugs that require total abstinence, SMA treatment's goal cannot be complete self-restraint from using social media as many students practically live online and obtain their leisure gratifications from it (Pantic et al., 2012). Instead, the ultimate therapy aim is controlled use of social media, a trend which also appears to be quite challenging due to social media being captivity (Niranjjan et al., 2017; Kuss \& Lopez-Fernandez, 2019).

Despite the growing evidence of alerts in various studies, little has been done in documenting literature that addresses preventing strategies of SMA effects (Lam et al., 2009; Vondrác \& Gabrhelík, 2016; Vasiliu \& Vasile, 2017; Kuss \& Lopez-Fernandez, 2019; Dubicka \& Theodosiou, 2020). Worse more, reliable information about SMA effects intervention strategies and treatment seems not to exist in Zambia. Regardless of that options have been proposed in the past decades on alleviating the problem. Such options have contributed to developing of preventive policies by various governments, particularly on safe online regulations. In Britain, a proposal was passed in 2019, which spelt out multiple rules in different social sectors. For instance, the British Government proposed that learning institutions should be setting up holistic approaches meant for creating appropriate online safety policies in an open discussion with the students (Dubicka \& Theodosiou, 2020). Conversely, a study was conducted by Gonzalez and Orgaz (2014) in Spain, which used a sample of 493 college students. The study 
recommended that school-based programs need to be instituted to reduce problematic social media use.

In support of the above, Alkaabi et al. (2017) recommended that colleges should be striving to adopt social media as an educational tool. The researchers further indicated that such a strategy, counter the harmful effects of addictive social media use. Other scholars have proposed Cognitive Behavioral Therapy (CBT) intervention as an additional random trial to mitigate SMA adverse (King et al., 2012; Tzawela et al., 2017). CBT is a standard treatment centred on the premise that student's thoughts regulate feelings. CBT strategy permits addicts to comprehend their addictive conduct as they learn new adapting aptitudes of counteractions (Young, 2014). To exemplify the issue, Young (2013) used CBT as the intervention strategy to treat comorbid problems arising from social media addiction using a sample of 128 participants. The participants were screened using Internet addiction test and therapy, which was done weekly. The investigation uncovered huge treatment indications of such side effects after it was directed reliably between the times of one to a half year.

Subsequently, the provision of guidance and counselling appears to be ideal for reducing the psychological effects. College counsellors are often professionals to become aware of the psychological problems of the students. They are mandated to work by ensuring that students who suffer from social media addiction problems receive the appropriate care level (Hagedom \& Young, 2011). Through counselling, students may be helped develop their understanding of who they are and be appropriately guided particularly on peer pressure, personality differences and intra and interpersonal conflict (Ndlovu, 2015) emanating from excessive social media usage. Despite having face-to-face counselling services in colleges, they are not used by many of the students who need support. Students are hesitant to seek professional help when they most need it (Rickwood et al., 2005). To this effect, Griffiths et al. (2013) highlighted that creating online support groups helps the counsellor in handling the problem.

As earlier alluded to regarding the Zambian context, little is known about the nature of SMA effects regulatory strategies meant for students in learning institutions. This is due to the lack of empirical studies centred on intervention strategies in the country. Indulgent in various SMA interventions approaches is critical since it can educate specialists and serve as a reason for future mediation contemplates. As such, it is an indisputable assertion that scarcity of studies in terms of demographic could result in faulty assumptions. Hence, research was born out of the need to explore strategies required to mitigate the effects of SMA on student's psychological well-being in colleges of education on the Copperbelt province of Zambia. In an attempt to accomplish the need, we raised two questions. These include;

1. What are the adverse effects of excessive social media usage on students' psychological well-being in colleges of education on the Copperbelt province of Zambia?

2. What strategies can be used to reduce social media addiction's effects on students' psychological wellbeing in colleges of education on Zambia's Copperbelt province?

\section{Significant of the study}

Intervention strategies in promoting psychological well-being amongst social media addictive students have been common-place for decades now in other countries apart from Zambia. As such, the study strives to fill up the observed demographic gap. Subsequently, understanding these strategies and approaches is critical. It can educate specialists and serve as a reason for future mediation contemplates, in turn, lessens the potential adverse outcomes prompted by addictive online media utilisation. Taking this broader approach may encourage prioritisation in policymaking and allocation of clinical resources for SMA effects early diagnosis. Besides, the study may likewise stimulate further exploration in a similar field.

\section{Method}

The interpretive philosophy anchored the methodology of this study. Interpretivist disagree that use of proven scientific methods, cannot find all truth, but through the in-depth descriptions of human experiences that scientific observations and experiments cannot determine (Hugly \& Sayward, 1987). In line with the assumptions espoused, this study employed a qualitative case study research design to have an in-depth comprehension of the issue under investigation. A total sample of 64 students drawn from 3 public (Mufulira College of Education, Kitwe College of Education, and Luanshya Technical Vocational and Training College) and 3 private (Mufulira Professional College, Nkana College of Education and Lubuto College of Education) colleges on the Copperbelt were selected for the study. Equally, two sampling techniques were utilised; stratified sampling to select colleges, whereas the students' selection was accomplished using simple random sampling.

The participants were selected because previously, they were subjected to Social Network Addiction Scale (SNAS) developed by Gokdas \& Kuzucu (2019). However, to provide a focused answer to the research questions in the preceding paragraph, the researchers designed an interview and FGD guide comprising a series of focusing statements and open-ended questions to initiate discussions. The statements derived from SNAS and topics included their points of view about study questions. Conversely, the researchers analysed the collected data using a framework analysis approach to generate study themes regarding the outcomes. The framework analysis approach is possibly the most famous qualitative analysis approach (Hackett \& Strickland, 2018). The researchers obtained 
ethical clearance from the University of Zambia ethical clearance committee, and the Ministry of General Education granted permission to conduct the study in the sampled colleges.

\section{Results}

In terms of sample categorisation, a total of sixty-four (64) participants took part in the study. Among them, twentytwo (22) Interviewees (I) (12 females and 10 males) took part in the interviews and forty-two (42) Discussants (D) (18 females and 24 males), participated in the FGDs which comprised six (6) groups. To ensure confidentiality, the interviewees are represented by the symbol letter $A$ to $J$ for male and a symbol number 1 to 12 for a female. As for the FGD, the discussants are represented by the symbol: FGD 1, 2, 3, 4, 5, and 6, respectively. The numbers 1 to 6 are symbols for a college where the discussants were drawn.

\section{Effects of Addiction to Social Media Usage}

Participants were asked to respond to the effects they thought using social media excessively had on their psychological well-being. The findings were grounded on three psychological indicators that include depression, anxiety and stress as presented below.

\section{Depression indicators}

When asked whether they had ever gotten depressed while using social media, all the participants' narrations yielded several symptoms that pointed to depression behaviour. These symptoms have been themed as restlessness, loss of interest in activities, getting tired from nowhere and emotionally exhausted (Table 1).

\begin{tabular}{|c|c|c|}
\hline Psychological & Theme & Extracted Narration on measure \\
\hline \multirow[t]{3}{*}{ Depression } & $\begin{array}{l}\text { Restlessness } \\
\text { (I-18 \& D-38) }\end{array}$ & $\begin{array}{l}\text { There is a lot of secret sensitive information such as videos, texts and } \\
\text { pictures that I keep in my Facebook account and the phone meant } \\
\text { for future use. I always feel insecure about keeping them, though I } \\
\text { have no choice. I keep on thinking that anyone with a sophisticated } \\
\text { mind can just come open and post them through Facebook without } \\
\text { my knowledge. If I accidentally leave the phone, I become restless } \\
\text { and develop a sense of insecurity. Iam ever online to check for such } \\
\text { potential predicaments friends post (FGD 4, 2019). }\end{array}$ \\
\hline & $\begin{array}{l}\text { Emotionally } \\
\text { exhausted } \\
\text { (I-16 \& D-35) }\end{array}$ & $\begin{array}{l}\text { Although I receive at least one or two likes when I post something } \\
\text { on social media, I don't feel that much happy most of the time. I feel } \\
\text { moody and weak, especially when I compare myself to my friends } \\
\text { who are ever boasting on the number of likes. I feel my colleagues } \\
\text { are happier and more successful than I am in this world of social } \\
\text { media (I B, 2019). }\end{array}$ \\
\hline & $\begin{array}{l}\text { loss of interest } \\
\text { in activities, } \\
\text { (I-19 \& D-36) }\end{array}$ & $\begin{array}{l}\text { Back home, when my mother confiscated my phone for a week. I felt } \\
\text { as if life had just crashed. I never even used to enjoy the meals, and } \\
\text { I used to have sleepless nights. It was because I kept on thinking } \\
\text { about how my followers were reacting to such a predicament. Worse } \\
\text { more, here at college, when the power goes, and such a situation } \\
\text { finds that I did not charge the phone, my life becomes horrible, } \\
\text { attending to my day's chores becomes hard. (I H, 2019). }\end{array}$ \\
\hline
\end{tabular}

\section{Anxiety indicators}

Overwhelmingly participants' preoccupied social media use had the potential to trigger anxiety and undermine their psychological well-being in different ways. Most of the participants reported having a feeling of tension, worries, and emotions when they came across the displeasing contents. Conversely, they used to compare with their followers to meet their self-evaluation needs. Some lovely comment 'likes' and posts gave them the impression that they were more prolific than others, while fewer 'likes' than their colleagues led them to question themselves, a situation which led them to experience feelings of inadequacy. The impressions provoked anxiety of wanting to be perpetually online as encapsulated in table 2 . 
Table 2: Anxiety indicators

\begin{tabular}{|c|c|l|}
\hline $\begin{array}{c}\text { Psychological } \\
\text { indicator }\end{array}$ & Themes (n) & \multicolumn{1}{|c|}{ Extracted narration on measure } \\
\hline \multirow{5}{*}{ Anxiety } & $\begin{array}{c}\text { Feeling of } \\
\text { tension and } \\
\text { worries } \\
\mathbf{I}-15 \text { \& D- } \\
\mathbf{4 0 )}\end{array}$ & $\begin{array}{l}\text { The digital world tends to exaggerate what is in us. The } \\
\text { combination of either partial or total anonymity means that } \\
\text { people often say things in a more indirect way when online than } \\
\text { they would do face-to-face. I have difficulties controlling my } \\
\text { worries each time I am contributing to a chat, particularly on } \\
\text { Facebook. People differ, and you will never know precisely your } \\
\text { friends' personalities you are chatting with (I 12, 2019). }\end{array}$ \\
\cline { 2 - 4 } & $\begin{array}{l}\text { Social } \\
\text { comparison } \\
\mathbf{I - 1 9} \& \mathbf{D}- \\
\mathbf{3 8 )}\end{array}$ & $\begin{array}{l}\text { When I don't receive more good comment than what my friends } \\
\text { does, I panic a lot. And more especially when I am cut off online } \\
\text { due to power outages initiated by ZESCO and when I don't have } \\
\text { bundles, I become anxious and restless because I always think } \\
\text { that I am the only one missing essential activity online (FGD 3, } \\
\text { 2019). }\end{array}$ \\
\hline
\end{tabular}

\section{Stress indicator}

Three categories emerged, regarding participants consensually views on their stressful life when in use of social media excessively. These categories include fear of missing out, fear of being judged and procrastination. Below are extracted comments that were advanced (Table 3 ).

Table 3: Stress indicators

\begin{tabular}{|c|c|c|}
\hline $\begin{array}{l}\text { Psychological } \\
\text { indicator }\end{array}$ & Theme(n) & Extracted narration on measure \\
\hline \multirow{3}{*}{ Stress } & $\begin{array}{c}\text { Fear of missing } \\
\text { out } \\
\text { (I-17 \& D-39) }\end{array}$ & $\begin{array}{l}\text { I fail to finish my meals without checking for updates and } \\
\text { messages on my phone. I eat with my right hand while holding the } \\
\text { phone on the left hand. Worse more, I can't leave to anywhere } \\
\text { without carrying the phone even when I am going to the toilet. I } \\
\text { just feel the urge of checking for notification and responding to } \\
\text { them immediately all the time (FGD1, 2019). }\end{array}$ \\
\hline & $\begin{array}{l}\text { Fear of being } \\
\text { judged and } \\
\text { untrustworthy } \\
\text { (I-16 \& D-36) }\end{array}$ & $\begin{array}{l}\text { Social media is another world, and I endure all type of trauma } \\
\text { resulting from being bullied, name-calling and backbiting on my } \\
\text { back whenever I crossed their feelings. You know, the wrong part } \\
\text { of social media is that you can't read how your friend is expressing } \\
\text { himself facially when chatting. Some pretend, as such, it becomes } \\
\text { hard for me to trust their stories. But that's how social media life } \\
\text { is; it's full of pressure, lies and induces hurt feelings. This time } \\
\text { around social media friends consider me to be boastful, and yet I } \\
\text { am not (I 6, 2019). }\end{array}$ \\
\hline & $\begin{array}{l}\text { Procrastination } \\
\text { and unsteadily } \\
\text { working } \\
\text { (I-21 \& D-39) }\end{array}$ & $\begin{array}{l}\text { I don't attend to other activities with my high spirit. I usually work } \\
\text { with a lot of breaks, coupled with mistakes. If I set myself time to } \\
\text { do college academic work, I sometimes entirely fail to do so as } \\
\text { planned. Most of the time, work is postponed. Worse more, I fail } \\
\text { to obey my self-timer set because of the prolonged period of } \\
\text { Facebooking. This is more stressful (I D, 2019). }\end{array}$ \\
\hline
\end{tabular}

\section{Strategies to Mitigate the Effects of Social Media Addiction}

This section presents the interventions strategies that were mostly agreed to by sample students concerning the raised questions in preceding paragraph. Three intervention levels (Government level, College level and Guidance and Counseling) were found to be vital for the study.

\section{Government level Interventions}

A high degree of agreement amongst the participants pointed on enactment of policies and regulations to combat the social media additive effects. Further majority of the participants indicated that incorporating digital effects in the college curriculum and investing in anti-addictive technology could also be of use. Extracts of verbatim are shown in table 4 below. 
Table 4: Government Intervention Level

\begin{tabular}{|c|c|c|}
\hline Category & Theme (n) & Extracted narration on measure \\
\hline \multirow{4}{*}{ Government } & $\begin{array}{l}\text { Enactment of } \\
\text { policies and } \\
\text { regulations } \\
(\mathrm{I}-16 \& \mathrm{D}-40)\end{array}$ & $\begin{array}{l}\text { Through parliament, the Government should enact strictly cyber-security } \\
\text { bills, cyber-crime bills, and data protection bills to curb the misuse of social } \\
\text { media. You know! They harm a lot, especially to those who are not strong, } \\
\text { as they develop psychological problems and at times, the situation may lead } \\
\text { to suicidal acts (FGD4,2019). }\end{array}$ \\
\hline & $\begin{array}{l}\text { Incorporate } \\
\text { digital effects in } \\
\text { the curriculum. } \\
(\mathrm{I}-17 \& \mathrm{D}-38)\end{array}$ & $\begin{array}{l}\text { In understand the adverse effects more; the curriculum should be the driving } \\
\text { force. The Government should awaken the Ministry of Education to include } \\
\text { it in some teachers training college courses. When the social media addictive } \\
\text { effects are discussed in class, it can make an impact, as students will fully } \\
\text { understand it. However, before inclusion, research should be the driving } \\
\text { force in the first instance to ascertain the feasibility of such incorporation } \\
\text { (FGD3, 2019). }\end{array}$ \\
\hline & \multirow{2}{*}{$\begin{array}{l}\text { Invest in anti- } \\
\text { addictive } \\
\text { technology } \\
\text { (I-18 \& D-39) }\end{array}$} & $\begin{array}{l}\text { It is essential to have anti-addictive devices that should be switching off } \\
\text { platforms once inappropriate usage is noticed. (FGD6, 2019). }\end{array}$ \\
\hline & & $\begin{array}{l}\text { The Government should be striving to collaborate with mobile firm } \\
\text { providers and a regulatory body ZCTA to develop mitigating strategies. In } \\
\text { this aspect, technological firms should develop software which should be } \\
\text { simple and yet powerful. The software should be designed fashionably so } \\
\text { that they can detect excessive use of social media. At the same time, it should } \\
\text { be censoring and blocking offensive comments automatically (I E, 2019). }\end{array}$ \\
\hline
\end{tabular}

\section{College Level Interventions}

Participants were asked on how college authority could reduce the adverse effects of social media addiction on students. Consensually, the strategies that participants narrated include, providing formally digital effect education, college online safety policies, and treating social media addict's effects in the same way just like drugs. Conversely, conducting research and seminars and parents or guardians' involvement was commonly narrated as strategies in mitigating the social media addiction effects (Table 5).

Table 5: College Level Interventions

\begin{tabular}{|c|c|c|}
\hline Category & Theme (n) & Extracted narration on measure \\
\hline \multirow{5}{*}{ College } & $\begin{array}{l}\text { Formally educate students } \\
\text { on digital impacts } \\
\text { (I-17 \& D-36) }\end{array}$ & $\begin{array}{l}\text { Involve us because we frequently undergo torture of being abused } \\
\text { and victims of abusing others. They must be a deliberate college } \\
\text { policy to formally educate us so that we understand the detrimental } \\
\text { effects (I } 2,2019) \text {. }\end{array}$ \\
\hline & $\begin{array}{l}\text { College Online safety } \\
\text { policies and strategies (I-18 } \\
\& \text { D-41) }\end{array}$ & $\begin{array}{l}\text { Colleges should develop online safety policies aimed at curbing } \\
\text { harassment and encouraging students not to hesitate to report any } \\
\text { unfair treatment that goes on online to the relevant college } \\
\text { authority (FGD5, 2019). }\end{array}$ \\
\hline & $\begin{array}{l}\text { Colleges to treat SM addicts } \\
\text { effects just like drugs (I-16 } \\
\text { \& D-37) }\end{array}$ & $\begin{array}{l}\text { Colleges should also be handling the digital effect just the same } \\
\text { way they handle drugs such as marijuana and fairness should be } \\
\text { followed when punishing victims (FGD6, 2019). }\end{array}$ \\
\hline & $\begin{array}{l}\text { Conducting Research and } \\
\text { Seminars } \\
\text { (I-22 \& D-39) }\end{array}$ & $\begin{array}{l}\text { Conduct research to ascertain the degree of social media addiction } \\
\text { effect prior enactment of strategies, as it may provide a base on } \\
\text { where to start from and where to end (I } \mathrm{H}, 2019) \text {. }\end{array}$ \\
\hline & $\begin{array}{l}\text { Parental/guardian } \\
\text { involvement } \\
\text { (I-17 \& D-38) }\end{array}$ & $\begin{array}{l}\text { Involve parents and guardians in the fight because they understand } \\
\text { their relatives fully in terms backgrounds. It became easier to } \\
\text { provide intervention if an individual's upbringing information is } \\
\text { well known (I B, 2019). }\end{array}$ \\
\hline
\end{tabular}

Guidance and Counseling Level Interventions

Participants were asked to bring forward their perspectives on how guidance and counselling could reduce social media addiction's adverse effects on students' psychological well-being. They consensually narrated opinions were analysed and categorised into three subheadings: Coping strategies mechanism and use of behavioural therapies; holding of both online and offline educative forums and collaboration with stakeholders. 
Table 6: Guidance and Counseling Level Interventions

\begin{tabular}{|c|c|c|}
\hline Category & Theme & Extracted narration on measure \\
\hline \multirow{8}{*}{$\begin{array}{l}\text { Guidance and } \\
\text { Counseling }\end{array}$} & \multirow{5}{*}{$\begin{array}{l}\text { Coping strategies } \\
\text { mechanism and } \\
\text { use of behavioural } \\
\text { therapies } \\
\text { (I-19 \& D-39) }\end{array}$} & $\begin{array}{l}\text { I feel considering a ten-day extremely digital detox could help, though } \\
\text { it requires a lot of commitment. I once did that, and it helped me a lot } \\
\text { to attend to other activities (FGD1, 2019). }\end{array}$ \\
\hline & & $\begin{array}{l}\text { Avoid talking to a stranger online; they lead to addictiveness as they } \\
\text { add to the number of people you interact with }(\mathrm{I}, \mathrm{H}, 2019) \text {. }\end{array}$ \\
\hline & & $\begin{array}{l}\text { Incorporate psychological theories such as cognitive behavioural } \\
\text { therapy, behaviour modification and social constructionist as tools for } \\
\text { counselling addicts (I 5, 2019). }\end{array}$ \\
\hline & & $\begin{array}{l}\text { Thought it is quite painful and hard to follow, students should be } \\
\text { striving to have a period of some good break. This may help to attend } \\
\text { to other things and reduce excessive use (I J, 2019). }\end{array}$ \\
\hline & & $\begin{array}{l}\text { Students should learn that phone notifications are quite distractive if } \\
\text { not appropriately handled. Switching off the phone notification for a } \\
\text { while and deleting some of the unused accounts may reduce } \\
\text { addictiveness (FGD4, 2019). }\end{array}$ \\
\hline & \multirow[t]{2}{*}{$\begin{array}{l}\text { Holding of both } \\
\text { online and offline } \\
\text { Educative Forums } \\
\text { (I-17 \& D-36) }\end{array}$} & $\begin{array}{l}\text { It is quite advantageous to some shy students because it becomes a } \\
\text { problem for such students when done in physical groupings; they } \\
\text { usually participate less. Sometimes, they get nothing from such face-to- } \\
\text { face discussions (FGD2, 2019). }\end{array}$ \\
\hline & & $\begin{array}{l}\text { Ifeel, enhancing educational forums aimed at discussing the addictive } \\
\text { social media effects could be ideal. Such platforms should be } \\
\text { encouraged at all cost in all colleges. It must be done monthly because } \\
\text { many things happen during the month (I I, 2019). }\end{array}$ \\
\hline & $\begin{array}{l}\text { Collaboration with } \\
\text { Stakeholders } \\
\text { (I-15 \& D-35) }\end{array}$ & $\begin{array}{l}\text { Collaborate with social media providers such as MTN Airtel and } \\
\text { ZAMTEL to provide sensitisations to better comprehend the rights and } \\
\text { responsibilities needed to reduce social media effects }(\mathrm{I} 8,2019) \text {. }\end{array}$ \\
\hline
\end{tabular}

\section{Discussion and conclusion}

Consistency with other studies, the current research identified notable symptoms of indicators that point toward evidence of depression, stress and anxiety (Pantic et al., 2012; Aydogan \& Buyukyilmaz, 2017; İbrahim, 2019). The symptoms are considered to effects arising from student's social media addictive behaviours. Consequently, the psychological indicators appear to demonstrate troubling conditions on students regarding their psychological well-being (Niranjjan et al., 2017). Since social media is, by all means, tempting and pervasive (İbrahim, 2019), the implication could be that underrating its outcomes might be hazardous on students. The situation may have a negative significant bearing when taken in the context of public mental health (American Psychiatric Association, 2013; WHO, 2017). Thus, the observation is timely, comprehensive analysis and interventions of its effects require urgent attention.

Regarding intervention, this study established that the Government should be striving to incorporate social media policies and regulations to protect addictive students. Creating a social media statutory regulatory framework has been a powerful preventing strategy in some countries that have adopted the approach (LopezFernandez, 2019; Dubicka \& Theodosiou, 2020). Despite the evidence incurred, the literature indicates that Zambia does not have a comprehensive legal structure to deter adverse social media usage behaviour among the youthful country populous (Hanyama \& Banda, 2017). The legal inadequacy may imply that they are many Jurisdictions gaps and weaknesses in the current Zambian social media code of conduct guideline. The situation could contribute to confusion and argument when coming up with social media laws by the lawmakers. As such, it necessitates the need for more specific law and regulations in the area of social media usage. However, we must indicate that before coming up with the country's social media regulatory framework, policy formulators should in the first place compare with other countries, probably with the use of research. More importantly, emulating with caution, the measures that have been put in place by developed countries in the enactment of policies seems to be prudent (Vondrác \& Gabrhelík, 2016; Dubicka \& Theodosiou, 2020).

One of the significant outcomes under college intervention was on the establishing of college online policies and regulation. However, the emphasis was placed on strict adherence, mainly when college authorities deal with suspected victims of problematic social media use. Consequently, an issue could arise. Since psychological problem are seen to be quite detrimental (Niranjjan et al., 2017), the student may consider concealing the effects mostly for fear of stigma. In such instances, addicts, especially those with personality disorders, conceal addictions, "they refuse responsibility for their feeling and assign responsibility to others" (Kaplan et al., 1994; 734). As such, 
we could say that authorities should be on high alert and should not be giving a blind eye to such behaviours. However, in an attempt to better comprehend the addictive social media usage context, the current study emphasised the inclusion of the digital harmful effects in the college curriculum. The strategy may make student understand better the effects.

In addition, the present study saw college counsellors as often the professionals who become aware of the students' psychological health problems. In this sense, the study established that guidance and counselling could advise students to manage their social media usage through behavioural therapy interventions. This finding relates to the literature, such as that of Young (2014), which advocated using cognitive behavioural therapy (CBT) as a strategy. Notably, the technique allows addicts to understand their addictive behaviour and learn new preventions' coping skills. However, this could be made possible only if relevant professionals incorporate psychoeducation about the harmful psychological effect of SMA, behavioural modification to control excessive social media use, cognitive restructuring and exposure to develop social skills (Young, 2014). Besides, the present study also acknowledged the frequency of holding the educative forum, where clients could freely discuss SMA issues. Despite the benefit that the meetings can harness, at times, introvert students tend to feel shy and may fail to open up when offline discussions are in process (Munsaka \& Matafwali, 2013). In such a view, the current study proposed using both modes (offline and online), which is assumed to be advantageous to all students with varying personalities.

\section{Conclusion}

Evidently, college students are at risk of significant deterioration in their psychological well-being, and the situation seems to be alarming. In that case, the current results offer a preliminary depiction of various strategies for regulating SMA effects. However, for reliability purposes, more research seems desirable, particularly those that should target other regions and institutions regarding the remediation of college students' social media addictive behaviours.

\section{Acknowledgments}

This work emerged from a thesis submitted to the University of Zambia school of Education in partial fulfilment for the honour of a Doctor of Philosophy in Education Psychology by the principal author. We thank the school of Education management for their educative contributions in the fulfilment of this study.

\section{References}

Alkaabi A., Sultan, Albion P. \& Redmond P. (2017). Social Network, Misuse in the classroom and Its Impact on male students motivation in UAE Tertiary Education. IAFOR. Journal of Education, Volume 5. Date accessed 15th September 2019.

American Psychiatric Association (2013). Diagnostic and Statistical Manual of Mental Disorders (5th ed.).Washington, DC: Author.

Aydogan, D. \& Buyukyilmaz, O. (2017). The Effect of Social Media Usage on Students' Stress and Anxiety: A Research in Karabuk University Faculty of Business International Journal of Multidisciplinary Thought. Issn: 2156-6992: 06(01):253-260.

Diagnostic and Statistical Manual of Mental Disorders (2017). American Psychiatric Association. Fifth Edition.

Dubicka, B. \& Theodosiou L. (2020). Technology use and the mental health of children and young people. College report CR225: Royal College of psychiatrists

Echeburúa, E. De Corral P. (2010). Addiction to new technologies and online social networking in young people: A new challenge. Addictions 22: 91-95.

Gökdaş İ. \& Kuzucu, Y. (2019). Social Network Addiction Scale: The Validity and Reliability Study of Adolescent and Adult Form. International Journal of Assessment Tools in Education, 6 (3), 396-414. DOI: 10.21449/ijate.505863.

González Ortega, E. \& Orgaz, B. (2014). Problematic online experiences among Spanish college students: Associations with Internet use characteristics and clinical symptoms. Computers in Human Behavior. 31. 151-158. 10.1016/j.chb. 10.038 .

Griffiths MD. (2013) Social networking addiction: Emerging themes and issues. Journal of Addiction Research and Therapy. 4(5): $1 \pm 2$.

Hackett A. \& Strickland K. (2018) Using the framework approach to analyse qualitative data: a worked example. Nurse Researcher. doi:10.7748/nr.2018.e1580.

Hagedorn W. B. \& Young T. (2011). Identifying and intervening with students exhibiting signs of gaming addiction and other addictive behaviours: Implications for professional school Counsellors. Professional School Counseling, 14(4), 250-260.

Hanyama C. \& Banda, D. (2017). Policies and Legislation for Internet Access and Usage in Zambia. Science and Technology 7(3): 72-78 Department of Electrical and Electronics, School of Engineering, University of 
Zambia, Lusaka. Date accessed 12 $2^{\text {th }}$ December, 2019, from DOI: 10.5923/j.scit.20170703.02.

Hugly, P \& Sayward C (1987) Relativism and Ontology, The Philosophical Quarterly, Volume 37, Issue 148, Pages 278-290, https://doi.org/10.2307/2220398.

İbrahim Tas, (2019). Association between Depression, Anxiety, Stress, Social Support, Resilience and Internet Addiction: A Structural Equation Modelling. Malaysian Online Journal of Educational Technology Date accessed 12th June 2020 from http://dx.doi.org/10.17220/mojet.2019.03.001.

Kaplan H.1., Sadock B.J \& Grebb J.A. (1994) Synopsis of Psychiatry. Behavioural Sciences, Clinical Psychiatry. Library of Congress Cataloging-in-Publishing Data. Baltimore, Maryland. USA.

King, D. L., Delfabbro, P. H., Griffiths, M. D., \& Gradisar, M. (2012). cognitive-behavioural approaches to outpatient treatment of internet addiction in children and adolescents. Journal of Clinical Psychology: In Session, 68(11), 1185-1195). doi:10.1002/jclp.21918.

Kuss Daria J \& Lopez- Fernandez (2019). Harmful Internet Use STOA- panel for the future of science \& Technology the UK.

Lam, L. T., Peng, Z., Mai, J. \& Jing, J. (2009). The association between Internet addiction and self-injurious behaviour among adolescents. Injury Prevention, 15, 403-408. Doi:10.1136/ip.2009.021949.

Munsaka \& Matafwali (2013). Human Development from Conception to Adolescence, Typical and Atypical Trends, University of Zambia Press: Lusaka.

Ndhlovu, D. (2015). Theory and Practice of Guidance and Counselling. UNZA press Lusaka.

Niranjjan R., Anand Raj., Prasad T \& Manikandan (2017). Prevalence of Internet Addiction and Effects of Social Media Usage among a Private Medical College Students, Pondicherry, International Journal of health Internet.

Pantic, I. (2014). Online social networking and mental health. Cyberpsychology, Behavior, and Social Networking, $\mathrm{X}(\mathrm{X}), 1-6$

Rickwood D, Deane F, Wilson C, Ciarrochi J. (2005). Young people's help-seeking for mental health problems. Aust J Adv Ment Health. 4(3):218-51.

Tzavela, E. C., Karakitsou, C., Halapi, E., \& Tsitsika, A. K. (2017). Adolescent digital profile: A process-based typology of highly engaged Internet users. Computer in Human Behavior, 69, 246-255.

WHO (2017). Depression and other common mental disorders in global health estimates. World Health Organization. Accessed on 12th May 2020 from https://apps.who.int/iris/bitstream/handle/10665/254610/WHO-MSD-MER-2017.2-eng.pdf

Vasiliu Octavian \& Vasile, Daniel (2017). Social Network Sites Addiction- A New Challenge for New Times. International Journal of Internet of Things and Web Services. Accessed $20^{\text {th }}$ June 2018 from http://www.iaras.org/iaras/journals/ijitws ISSN: 2367-

Vondrác,"K.P. \& Gabrhelík, R. (2016). Prevention of Internet Addiction: A systematic review. Department of Addictology, First faculty of medicine, Charles University in Prague, and General University Hospital in Prague, Prague, Czech Republic. Accessed 26 ${ }^{\text {th }}$ June, 2018 from Doi: 10.1556/2006.5.2016.085.

Young, K. S. (2013). Treatment outcomes using CBT-IA. with Internet-addicted patients. Journal of Behavioral Addictions 2(4), pp. 209-215 (2013) DOI: 10.1556/JBA.2.2013.4.3.

Young, K. S. (2014). CBT-IA: The first treatment model for internet addiction. Journal of Cognitive Psychotherapy: An International Quarterly, 304-312. doi:10.1891/0889-8391.25.4. 